\title{
Arethusa Bulbosa, An Addition to The Flora of Saskatchewan
}

\section{by George W. Argus, University of Saskatchewan, Saskatoon}

An interesting orchid, Arethusa bulbosa L., has recently been discovered in northwestern Saskatchewan. The discovery of this lovely orchid not only adds a new species to the flora of Saskatchewan, but extends the range of an eastern American species about 480 miles and raises some interesting ecological questions.

From June 26 to July 11, 1962, an Institute for Northern Studies expedition was exploring the sand dune region on the south shore of Lake Athabasca, just east of the William River (see Ledingham, Blue Jay $20(3): 98-102$. 1962). It was in a bog along the south edge of these dunes that Arethusa bulbosa was found.

Arethusa is a striking orchid standabout 15 to $25 \mathrm{~cm}$. tall and bearing a solitary, showy, rose-purple flower on an apparently leafless scape. A single linear-lanceolate leaf begins to develop shortly after flowering, and becomes well developed during fruit. The plant is loosely rooted-in Sphagnum and bears a bulbous corn at its base. A quotation from Donovan Correll (1950) is particularly descriptive: "Its beautifully colored flower is held primly erect by the rigid scape, and strangely enough it has the appearance of a fanciful little beast, with

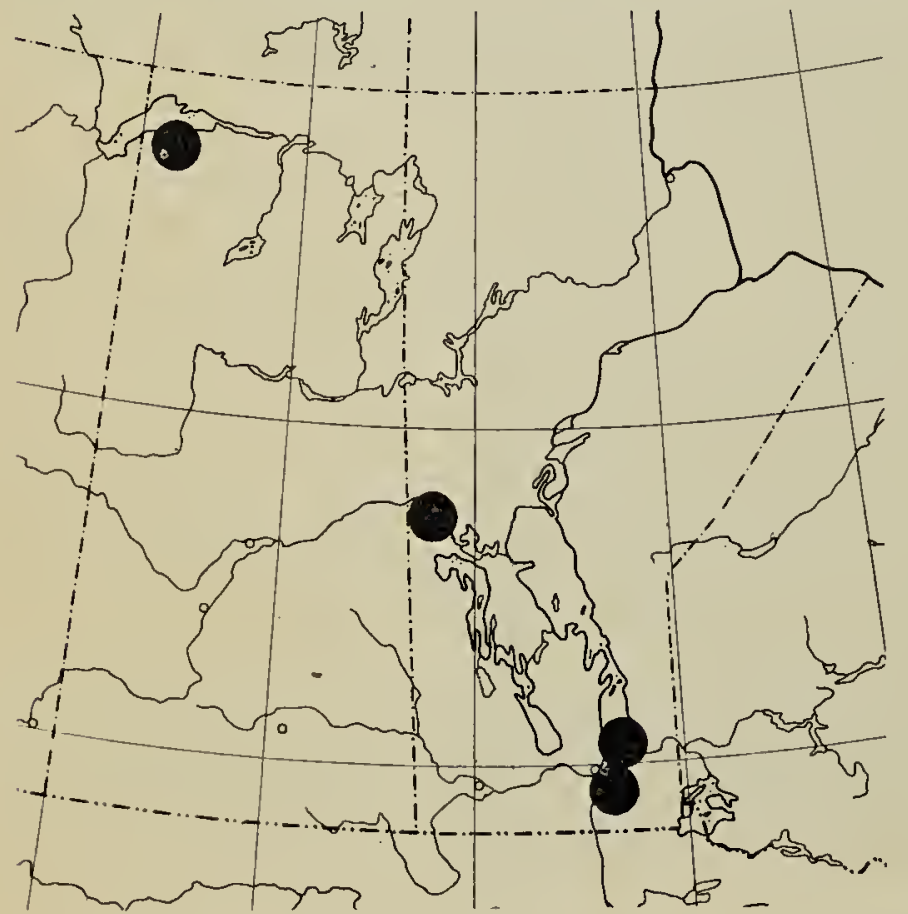

Distribution of Arethusa bulbosa in Saskatchewan and Manitoba. The localities are from Scoggan, 1957. ears distended and lolling tongue, straining to recognize the intruder of its peaceful haunts." One of its common names, Dragon's-mouth, reflects this aspect. Other common names applied to this orchid are Swamppink, Wild Pink, Bog-rose, and Arethusa, the name of a mythical river nymph.

Its "peaceful haunts" in this case is a wet Sphagnum bog along the edge of Little Gull Lake, adjacent to active sand dunes. The bog area is about two miles long and one mile wide and actively being invaded by sand. The bog is very wet and contains a network of shallow inlets which dissect it into a complex of irregular peninsulas and small bog islands. Arethusa is locally abundant in this habitat, particularly on the bog islands, and is associated with the following species.

Picea mariana (Black Spruce)

Larix laricina (Larch)

Carex pauciflora (A new record for Saskatchewan)

C. paupercula var. irrigua (Bog Sedge)

Eriophorum vaginatum ssp. spissum (Loose-sheathed Cotton-grass)

Scirpus hudsonianus (Alpine cotton-grass)

Sarracenia purpurea (Pitcherplant)

Drosera anglica (Oblong-leaved Sundew)

D. linearis (Slender-leaved Sundew)

Andromeda polifolia (Bog Rosemary)

Chamaedaphne calyculata (Leatherleaf)

Ledum groenlandicum (Labrador Tea)

Oxycoccus quadripetalus (Small Cranberry)

Sphagnum spp.

Atlhough numerous bogs were visited during the summer of 1962, further search for Arethusa was futile. Even in the general area of Little Gull Lake this species seemed to be restricted to this one bog. In general, this species is rare, but where it does occur it is locally abundant. Surch a 
distribution may be expected at the edge of a species range, but it may also reflect an irregular distribution of a particular bog environment favorable to the establishment and growth of this species. The occurrence in this bog of other species of limited distribution in this general region, including Drosera linearis, Sarracenia purpurea, and Carex pauciflora, also suggest that this bog is unusual in some way. It is unknown why this bog supports certain southerrn and eastern bog species which are generally uncommon or absent elsewhere in northern Saskatchewan. In the case of Arethusa it may be as simple as a smaller rodent population which reduces the amount of predation on Arethusa corms. However, it is more likely to be influenced by a complex of climatic, physiographic, biotic, and phytogeographic factors. A detailed study of the distribution of bog species and the bog habitat in Saskatchewan will help to answer this question.
The distribution of Arethusa bulbosa is primarily eastern American. It occurs throughout New England southward into the mountains of the Carolinas and westward through the Lake States to Minnesota. In the north it ranges from Newfoundland, Nova Scotia, and New' Brunswick westward to Manitoba, and, now, Saskatchewan. Its distribution in Manitoba and Saskatchewan (see map) suggests that it could be expected to occur throughout some of the boreal forest region between The Pas and Lake Athabasca. Exploration of bogs in northern Saskatchewan, particularly in the vicinity of the Hansen Lake Road and the Churchill River Road, may fill a gap in our knowledge of the distribution and ecology of Arethusa bulbosa.

\section{LITERATURE CITED}

CORRELL, D. 1950. Native orchids of North America north of Mexico. Chronica Botanica Co., Waltham, Mass.

SCOGGAN, H. J. 1957. Flora of Manitoba. Nat. Mus. Canada Bull. 140.

\section{Plants of Eroded Hillsides}

\section{by K. F. Best, Swift Current}

Still dealing with our dry hillsides and eroded areas, perhaps. we should take care lest we become like the man who could not see the forest for the trees. On our hills, two plants in particular are found in great pro- fusion, but we often fail to notice them. One is a small moss-like species, the other, a mat-forming phlox.

Although not generally noticed, one of the commonest and most

\section{PRAIRIE SELAGINELLA}

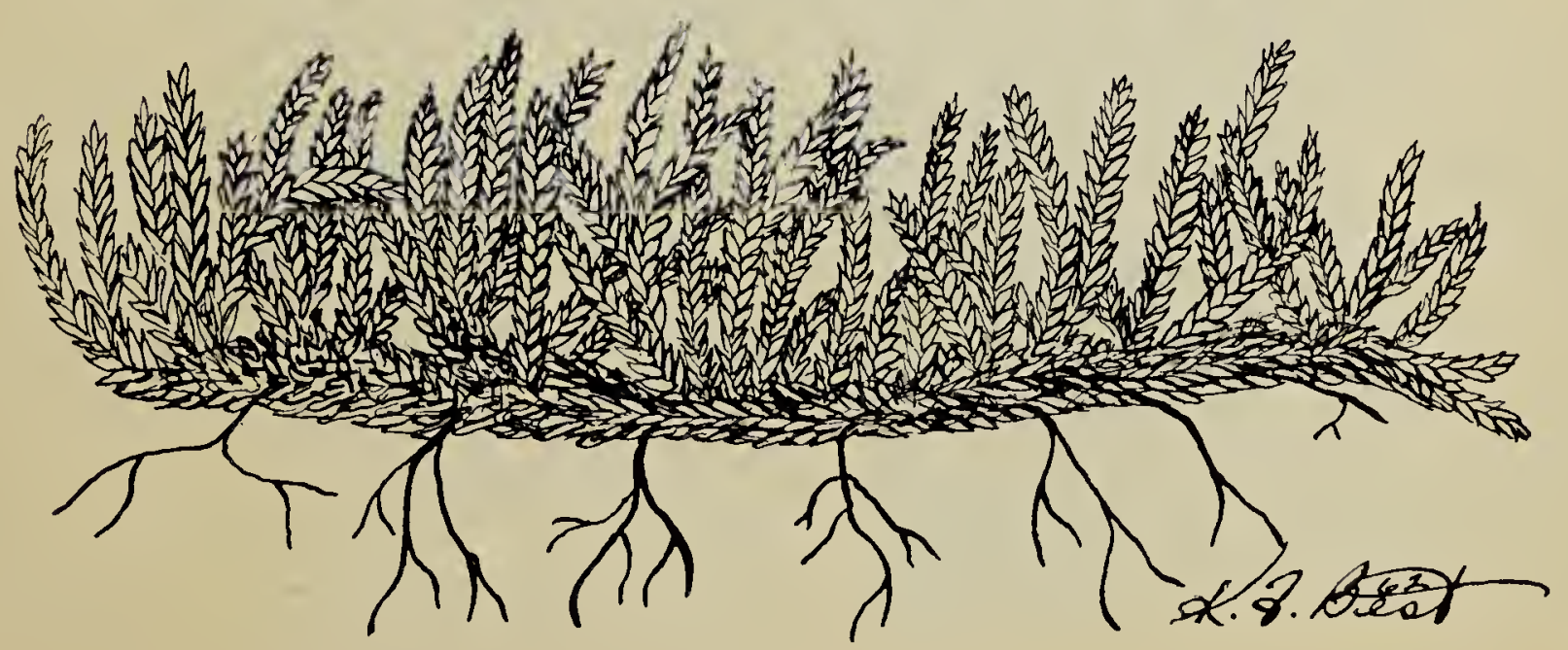

